\title{
A preliminary simulated iron fortification trial in South Indian preschool children
}

\author{
By SHEILA M. PEREIRA, ALMAS BEGUM, V. I. MATHAN \\ AND S. J. BAKER \\ Nutrition Research Unit and Wellcome Research Unit, Christian Medical College \\ and Hospital, Vellore, India
}

(Received I August 1978 - Accepted 21 September 1978)

\begin{abstract}
1. The effect of fortification of food with iron to provide $10 \mathrm{mg}$ elemental $\mathrm{Fe} / \mathrm{child}$ per $\mathrm{d}$ was studied in preschool children maintained on a cereal diet, over a 5-month period.

2. The absorption of $5 \mathrm{mg} \mathrm{Fe}$ as ferrous sulphate mixed in one meal was $3.3 \%$ of the test dose and when $3.3 \mathrm{mg}$ was given with each of three meals over a $2 \mathrm{~d}$ period the corresponding value was $4.8 \%$.

3. The mean absorption of a test dose of ferrous ascorbate studied in twenty-four children midway through the trial was $42 \%$.

4. The only beneficial effect of Fe fortification in this time-period in the experimental group was the prevention of the decrease in packed cell volume which occurred in the control group.
\end{abstract}

Iron supplementation of $20-30 \mathrm{mg}$ inorganic $\mathrm{Fe} / \mathrm{d}$, given between meals to preschool children was successful in significantly improving their Fe nutritional status within a period of 3 months (Pereira et al. 1978). However, supplements of this order cannot be provided by food fortification. If $\mathrm{Fe}$ deficiency is to be combated by fortification of foodstuffs it must be shown that the lower level of supplementation, which can be achieved by this means, is beneficial.

The following studies were undertaken to assess the effect of a feasible level of food fortification with $\mathrm{Fe}$ in preschool children maintained on a high-cereal diet.

\section{MATERIAL AND METHODS}

Preschool children 2-5 years of age living in a residential home were the subjects of the study. The children were admitted after a medical examination which included a skiagram of the chest. Children with tuberculosis and other chronic diseases were excluded. All were in apparent good health and none was infested with hookworm (Ancylostoma duodenale). Informed consent was obtained from the children's parents or legal guardians for their participation in the trial. Blood was taken without venous stasis, after an overnight fast, for the determination of haematological status. Haemoglobin was estimated by the cyanmethaemoglobin method using a photoelectric colorimeter, checked periodically against an international reference standard. Packed cell volume was measured by the use of a micro-haematocrit centrifuge. Serum Fe was determined by the method recommended by the International Committee for Standardization in Haematology (197I) and the unsaturatedFe-binding capacity by the method of Herbert et al. (1966). Serum vitamin $B_{12}$ was estimated using Euglena gracillis $\mathrm{Z}$ strain (Hunter et al. 1956) and serum folic acid by the technique of Waters \& Molin (196I), using Lactobacillus casei as the test organism. The estimations were repeated 5 months later. Before the study was undertaken all the children had received supplements of cyanocobalamin and folic acid and the concentrations of these nutrients were at normal levels throughout the trial period.

The children were paired on the basis of their height, serum $\mathrm{Fe}$ and haemoglobin con- 
centration. One of each pair was assigned to an experimental group receiving an Fe-fortified diet and the other to a control group.

The diet, given to all the children, provided their requirements of energy and protein from cereals (millet (Eleusine coracana) and rice) pulses, vegetables and fruits (WHO, I973). Millet was eaten at breakfast and rice at the other meals. Animal foods were not included. The average Fe content of the diet was $18 \mathrm{mg} \mathrm{Fe} / 4 \cdot \mathrm{I} 8 \mathrm{MJ}$ eaten, as estimated by the method of Elvehjem (I930). The diet supplied an average ( \pm SE) of $\mathrm{I} \cdot 62( \pm 0.05) \mathrm{mg} \mathrm{Fe} / \mathrm{kg}$ bodyweight per $\mathrm{d}$.

Ferrous sulphate, to provide a daily supplement of $10 \mathrm{mg}$ inorganic $\mathrm{Fe} / \mathrm{child}$, was mixed into and cooked with the food given to the experimental group at breakfast and dinner when a weighed amount was served to each child and its consumption assured.

Heights were measured every month, the average of three readings being recorded. The average of the weights on three consecutive days was recorded every 2 weeks. A daily record of morbidity was maintained by trained resident staff.

The absorption of $\mathrm{Fe}$ was measured by radioisotopic studies using a moving-bed, shadow-shield, whole-body counter. In the twenty-four subjects in the experimental group the absorption of the supplement of $5 \mathrm{mg}$ elemental $\mathrm{Fe}$ labelled with $\mathrm{I} \mu \mathrm{Ci} \mathrm{Fe}{ }^{59}$ was tested at the beginning of the experiment. The Fe was added to one curry dish before cooking and served as described previously. Each child was given an equal portion of this dish containing $5 \mathrm{mg}$ inorganic Fe which he ate in a normal manner with the cereal (millet). The complete consumption of the meal was assured. In the same twenty-four subjects, II weeks after the start of the supplementation, the absorption of a reference dose of $\mathrm{Fe}$ was measured. This dose consisted of $3 \mathrm{mg}$ elemental $\mathrm{Fe}$ in the form of freshly-prepared ferrous ascorbate, labelled with $\mathrm{I} \mu \mathrm{Ci} \mathrm{Fe}^{59}$ given after an overnight fast. In the subjects in the control group, the absorption of ferrous sulphate supplying $10 \mathrm{mg}$ inorganic $\mathrm{Fe} / \mathrm{d}$ and mixed with I $\mu \mathrm{Ci} \mathrm{Fe}{ }^{59}$, was tested over a $2 \mathrm{~d}$ period. Inorganic $\mathrm{Fe}(3.3 \mathrm{mg})$ was added to a curry dish before cooking and fed to the children three times daily for $2 \mathrm{~d}$.

\section{RESULTS}

The Fe absorption (mean \pm I SE) from the $5 \mathrm{mg}$ dose added to one meal was $3.3 \pm 0.28 \%$ in twenty-four children. The Fe absorption (mean $\pm \mathrm{I} \mathrm{SE}$ ) from the $3.3 \mathrm{mg}$ added to each meal over the $2 \mathrm{~d}$ period was $4.8 \pm 0.38 \%$ in the children in the control group. The absorption of the reference dose of $3 \mathrm{mg}$ elemental $\mathrm{Fe}$ in the twenty-four children in the experimental group after I I weeks of supplementation was $42 \cdot 2 \%$ (SE $2 \cdot 96$ ).

Twenty-two pairs of children completed the 5 months on the trial. Their haematological status, height and weight at the beginning and end of the study are shown in Table $I$.

In the control group the final value of the packed cell volume was significantly lower than the initial value $(P<0.01)$. The difference between the groups in packed cell volume and the other measurements were not significant.

The pattern of illness was similar in both groups of children (Table 2). Those in the control group had slightly more episodes of respiratory infection than the children in the group receiving extra $\mathrm{Fe}$. In the control group, there were seven children who had had one to two episodes each, four children who had three episodes and two children who had four episodes each whereas in the fortified group, eight children had one to two episodes of upper respiratory infection each and only one child had three attacks. The differences in the episodes of respiratory infection between the two groups were not of statistical significance, probably because of the small numbers of subjects studied. 


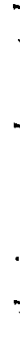

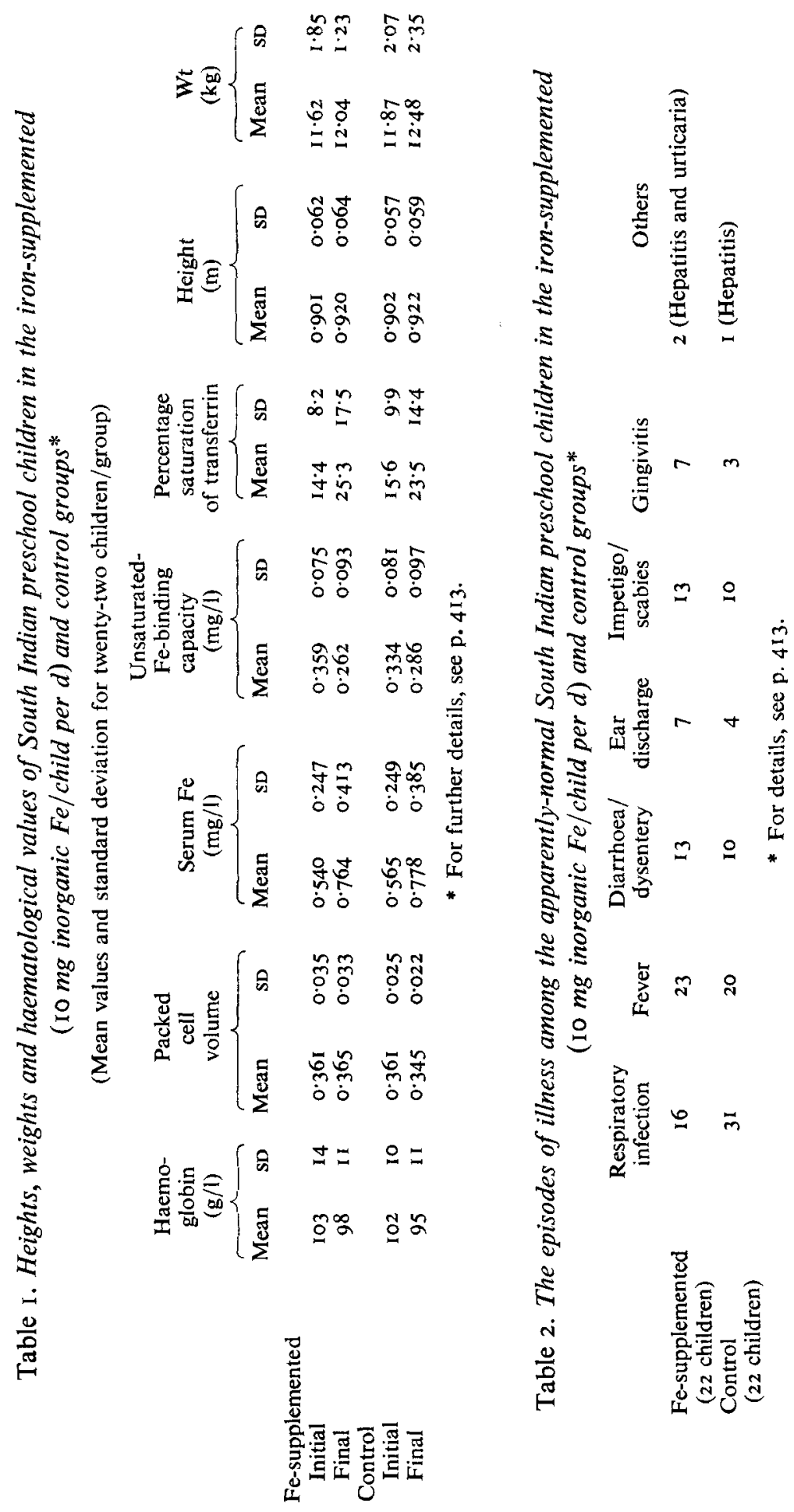




\section{DISCUSSION}

There is a lack of information on the absorption of fortification Fe by preschool children consuming cereal- and vegetable-based diets. Comparisons have therefore to be made with results obtained in adults given cereal diets. In one study, salt (sodium chloride) fortified with ferrous sulphate to provide an Fe supplement of $3 \mathrm{mg}$, was cooked with rice, lentils and vegetables and eaten by Fe-deficient Indian women resident in South Africa. The average absorption of the supplement was $3.5 \%$ with a range of $0.6-\mathrm{Ir} \cdot 7 \%$ (Sayers et al. 1974). In another study, $4.9 \%$ of a supplement of ferrous sulphate baked in wheat bread was absorbed by women who were not Fe deficient (Cook et al. 1973). The percentage absorption in the present study, where $3.3 \%$ of the supplement was absorbed at a single meal and $4.8 \%$ absorbed when the supplement was added to six meals fed over $2 \mathrm{~d}$, wascomparable to that found in these two studies in adults. In the present study better absorption was obtained when the supplement was fed over a $2 \mathrm{~d}$ period than when offered at a single meal. There are several factors which would account for the difference. The absorption of $\mathrm{Fe}$ is adversely influenced by the amount of phytin-phosphorus in the diet and favourably by the presence of ascorbic acid. The lower mean absorption of the supplement fed at one meal probably reflects the adverse effect of the negligible amount of ascorbic acid as compared with the better absorption over the $2 \mathrm{~d}$ period when the daily intake of ascorbic acid was $33 \mathrm{mg}$ (Layrisse et al. 1974; Sayers et al. 1974). In fact the presence of phytin-P did not appear to influence absorption as the ratio phytin-P:Fe was relatively higher over the $2 \mathrm{~d}$ period $(29 \mathrm{mg} / \mathrm{mg} \mathrm{Fe}$ ) than at the one meal ( $21 \mathrm{mg} / \mathrm{mg} \mathrm{Fe}$ ). Further, it is well established that the absorption of $\mathrm{Fe}$ varies from subject to subject and also from day-to-day in the same individual (Cook et al. I969).

Assuming that the blood volume of preschool children is $80 \mathrm{ml} / \mathrm{kg}$ (Smith, 1972) the absorption of $\mathrm{Fe}$, at $3.3 \%$ level, from the supplemental and food $\mathrm{Fe}$ would result in the accumulation of $142.5 \mathrm{mg}$ over the trial period. Fe losses, estimated at $0.13 \mathrm{mg} / \mathrm{d}$, amounted to $19.5 \mathrm{mg}$ and the requirement for growth, estimated at $0.22 \mathrm{mg} / \mathrm{d}$, was $33 \mathrm{mg}$ (Bothwell \& Finch, I962), leaving $90 \mathrm{mg}$ absorbed Fe, available for increases in haemoglobin. Allowing for the increase in blood volume resultant on growth, the haemoglobin value of the supplemental group should have increased by $24 \mathrm{~g} / \mathrm{l}$. In contrast to this theoretical projection, the children in the supplemented group showed a slight decrease in the average haemoglobin concentration though it was not as marked as that in the unsupplemented group. The only detectable benefit in the supplemented group was the prevention of the decrease in packed cell volume which occurred in the control children.

The absorption of the reference dose of ferrous ascorbate was carried out I I weeks after the supplementation was started. It is obvious from the average absorption of $42 \%$ of the reference dose, that many of the children were still Fe deficient and that decreasing absorption as Fe nutritional status improved can probably not explain the failure of haemoglobin to increase. The children were affected by a variety of minor illnesses and it is possible that these interfered with $\mathrm{Fe}$ absorption or utilization or both. Other factors, as yet unknown, may also have played a part.

The difficulties of demonstrating positive benefits following iron supplementation and fortification in an industrialized country have been summarized by Elwood (1968). In the present study, despite theoretical considerations, the only demonstrable benefit was the maintenance of the packed cell volumes in the children receiving the fortified diet.

Longer-term trials are necessary to establish the benefits, if any, of food fortification in populations eating vegetarian diets. 
These studies were supported by PL 480 agreement No. OI-002-N, Amend 2, National Institutes of Health and the World Health Organization.

\section{REFERENCES}

Bothwell, T. H. \& Finch, C. A. (1962). Iron Metabolism, p. 302. London: J. \& A. Churchill Ltd.

Cook, J. D., Layrisse, M. \& Finch, C. A. (1969). Blood 33, 421.

Cook, J. D., Minnich, B., Moore, C. V., Rasmussen, A., Bradley, W. B. \& Finch, C. A. (1973). Am. J. clin. Nutr. 26, 86I.

Elvehjem, C.A. (1930). J. biol. Chem. 86, 463.

Elwood, P. C. (1968). Proc. Nutr. Soc. $27,14$.

Herbert, V., Gottlieb, C. W., Lau, K. S., Fisher, M., Gevirtz, N. R. \& Wasserman, L. R. (1966). J. Lab. clin. Med. 67, 855 .

Hunter, S. H., Bach, M. K. \& Ross, G. I. M. (1956). J. Protozool. 3, 1017.

International Committee for Standardization in Haematology (197I). Br. J. Haemat. 20, 45I.

Layrisse, M., Martinez-Torres, C. \& Gonsalez, M. (1974). Am. J. clin. Nutr. 27, 52.

Pereira, S. M., Almas Begum \& Baker, S. J. (1978). Br. J. Nutr. 39, 493.

Sayers, M. H., Lynch, S. R., Charlton, R. W., Bothwell, T. H., Walker, R. B. \& Mayet, F. (1974). Br. J. Nutr. 31, 367.

Smith, C. H. (1972). In Blood Diseases of Infancy and Childhood, 3rd ed. p. 15 [C. H. Smith, editor] St Louis, Miss.: C. V. Mosby Co.

Waters, A. H. \& Molin, D. L. (1961). J. clin. Path 14, 335.

WHO (1975). Tech. Rep. Ser. Wld. Hlth. Org. no. 522. 